\title{
Germacrone derivatives: synthesis, biological activity, molecular docking studies and molecular dynamics simulations
}

\author{
Jie Wu ${ }^{1}$, Yu Feng ${ }^{1}$, Chao Han ${ }^{1}$, Wu Huang ${ }^{3}$, Zhibin Shen ${ }^{4}$, Mengdie Yang ${ }^{2}$, Weiqiang \\ Chen $^{2}$, Lianbao Ye ${ }^{1}$ \\ ${ }^{1}$ School of Pharmacy, Guangdong Pharmaceutical University, Guangzhou 510006, China \\ ${ }^{2}$ School of Basic Courses, Guangdong Pharmaceutical University, Guangzhou 510006, China \\ ${ }^{3}$ Inspection and Quarantine Technology Center of Zhanjiang Entry-Exit Inspection and Quarantine Bureau, Zhanjiang \\ 524001, China \\ ${ }^{4}$ School of Traditional Chinese Medicine, Guangdong Pharmaceutical University, Guangzhou 510006, China
}

Correspondence to: Lianbao Ye, email: yelb7909@163.com

Keywords: germacrone derivative, biological activity, c-Met kinase, molecular docking, molecular dynamics simulations

Received: September 30, 2016

Accepted: January 13, 2017

Published: January 27, 2017

\section{ABSTRACT}

\begin{abstract}
Germacrone is one of the major bioactive components in the Curcuma zedoaria oil product, which is extracted from Curcuma zedoaria Roscoe, known as zedoary. The present study designed some novel germacrone derivatives based on combination principles, synthesized these compounds, and investigated their inhibitions on Bel7402, HepG2, A549 and HeLa cells. Meanwhile, the study evaluated inhibitions of these derivatives on c-Met kinase, which has been detected in a number of cancers. The results suggested that the majority of the compounds showed stronger inhibitory effect on cancers and c-Met kinase than germacrone. Furthermore, our docking experiments analyzed the results and explained the molecular mechanism. Molecular dynamics simulations were then applied to perform further evaluation of the binding stabilities between compounds and their receptors.
\end{abstract}

\section{INTRODUCTION}

Rhizoma Curcuma belongs to the Zingiberacea family, which is composed of about 70 species of rhizomatous herbs at home and abroad, with approximately 20 species existing in China. In China, it is traditionally used for the treatment of dyspepsia, flatulence, menstrual disorders, fever, and cough [1]. Zedoary's extract have analgesic, antitumor, antimicrobial, and antiallergic activity [2-6]. Germacrone is a main bioactive constituent found in Zedoary oil product which is extracted from Curcuma zedoaria Roscoe [7]. The Germacrone (Figure 1) presents extensive bioactivities including antiulce, antiinflammatory, depressant, vasodilator, antibacterial, choleretic, antitussive, antitumor, antifeedant, antifungal and hepatoprotector effects [8-10].

The c-Met signaling pathway plays imperative roles in embryogenesis and early development; whereas c-Met is expressed by most carcinomas and its elevated expression relative to normal tissue has been detected in a number of cancers [11-13]. Activation of the HGF/c-Met signaling pathway has been shown to lead to a wide array of cellular responses including motility, survival, scattering, wound healing, invasion, angiogenesis, proliferation, tissue regeneration and branching morphogenesis [14-16]. Therefore, c-Met has become an attractive target of antitumor therapy.

References reported that carboxylic esters, especially aromatic esters, had strong anticancer activity. In the present study, carboxylic esters were introduced to germacrone to obtain novel germacrone derivatives (3a-3e) (Figure 2) based on the combination principles. It is hoped that introduction of carboxylic esters can increase anticancer activity of germacrone. Hopefully, it can absorb and distribute to various tissues quickly.

In the present study, we synthesized these compounds and evaluated their inhibitions on Bel-7402, HepG2, A549 and HeLa cells. Meanwhile, the study investigated inhibition of these derivatives on c-Met kinase, which has been overexpressed in a number of cancers. Further, the molecular mechanisms of these compounds to c-Met kinase were explained by docking experiments. The further evaluation of the binding stabilities between compounds and their receptors were performed by molecular dynamics simulations. 


\section{RESULTS AND DISCUSSION}

\section{Chemistry}

The target compounds $(2,3 \mathrm{a}-3 \mathrm{e})$ were prepared according to Scheme 1. The (3E,7E)-3,7-dimethyl-10(propan-2-ylidene)cyclodeca-3,7-dien-1-yl-acetate (3a), (3E,7E)-3,7-dimethyl-10-(propan-2-ylidene)cyclodeca3,7-dien-1-yl-4-methylbenzoate(3b),(3E,7E)-3,7-dimethyl10-(propan-2-ylidene)cyclodeca-3,7-dien-1-yl-3-methylbenzoate(3c),(3E,7E)-3,7-dimethyl-10-(propan-2-ylidene) cyclodeca-3,7-dien-1-yl-4-(trifluoromethyl) benzoate (3d), (Z)-(3E,7E)-3,7-dimethyl-10-(propan-2-ylidene) cyclodeca-3,7-dien-1-yl-3-phenylacrylate (3e) were obtained via DMAP/DCC esterification reaction with yields of $67 \%, 62 \%, 47 \%, 53 \%, 60 \%$.This reaction was carried out by using dry DCM or acetonitrile as a solvent, DCC as a dehydrator and DMAP as a catalyst and can provide a range of applicability. Due to the distinct difference in polarity, these compounds can be separated easily by silica gel column chromatography. Structural modification of germacrone and a systematic study revealed that the 8-hydroxy might be further optimization studies and a range of substituent would be suitable for this position.
The derivatives were characterized by ${ }^{1} \mathrm{H}$ NMR, ${ }^{13} \mathrm{C}$ NMR, elemental analyses and EI-MS. The analytical data for target compounds can be seen from Experimental and ${ }^{13} \mathrm{C}$ NMR and EI-MS gave information about carbon atoms and all the ion peaks corresponding to molecular weight of confirmed novel compounds.

(3E,7E)-3,7-dimethyl-10-(propan-2-ylidene) cyclodeca-3,7-dienol (2) Yield: 84\%, ${ }^{1} \mathrm{H}$ NMR (400 $\left.\mathrm{MHz}, \mathrm{CDCl}_{3}\right) \delta 5.29(\mathrm{dd}, \mathrm{J}=11.1,9.6 \mathrm{~Hz}, 1 \mathrm{H}), 5.2-5.1$ $(\mathrm{m}, 1 \mathrm{H}), 4.4(\mathrm{dd}, \mathrm{J}=5.4,1.9 \mathrm{~Hz}, 1 \mathrm{H}), 2.6(\mathrm{dd}, \mathrm{J}=12.6$, $11.3 \mathrm{~Hz}, 1 \mathrm{H}), 2.6-2.5(\mathrm{~m}, 1 \mathrm{H}), 2.5(\mathrm{~d}, \mathrm{~J}=1.9 \mathrm{~Hz}, 1 \mathrm{H}), 2.4$ (m, 1H), 2.4-2.3 (m,1H), $2.32(\mathrm{~m}, 1 \mathrm{H}), 2.31-2.25(\mathrm{~m}, 2 \mathrm{H}), 1.7$ (s, 6H), 1.57 (s, 3H), 1.55 (s, 3H). ${ }^{13} \mathrm{C}$ NMR(100MHz, $\left(\mathrm{D}_{6}\right)$ DMSO) $\delta 138.3$ (C-11), 137.2 (C-4), 131.7 (C-10), 129.4 (C-1), 129.2 (C-7), 120.1 (C-5), 71.8 (C-8), 39.2 (C-3), 38.6 (C-9), 28.8 (C-6), 25.6 (C-2), 21.4 (C-12), 21.4 (C-13), 18.8 (C-14), 16.3 (C-15). EI-MS: 221.35[M+H ${ }^{+}$]. Anal.Calcd for $\mathrm{C}_{15} \mathrm{H}_{24} \mathrm{O}$ (220.18): C, 81.76; H, 10.98; O, 7.26. Found: C, 81.76; H, 10.95; O, 7.29.

(3E,7E)-3,7-dimethyl-10-(propan-2-ylidene) cyclodeca-3,7-dien-1-yl-acetate (3a) Yield: 67\%, ${ }^{1} \mathrm{H}$ NMR $\left(400 \mathrm{MHz}, \mathrm{CDCl}_{3}\right) \delta 5.52(\mathrm{dd}, \mathrm{J}=5.8,1.3 \mathrm{~Hz}, 1 \mathrm{H}), 5.31$ $(\mathrm{dd}, \mathrm{J}=11.1,9.6 \mathrm{~Hz}, 1 \mathrm{H}), 5.13(\mathrm{dd}, \mathrm{J}=11.3,7.0 \mathrm{~Hz}, 1 \mathrm{H})$, $2.54(\mathrm{dd}, \mathrm{J}=10.5,6.5 \mathrm{~Hz}, 2 \mathrm{H}), 2.46(\mathrm{dd}, \mathrm{J}=15.8,1.3 \mathrm{~Hz}$,

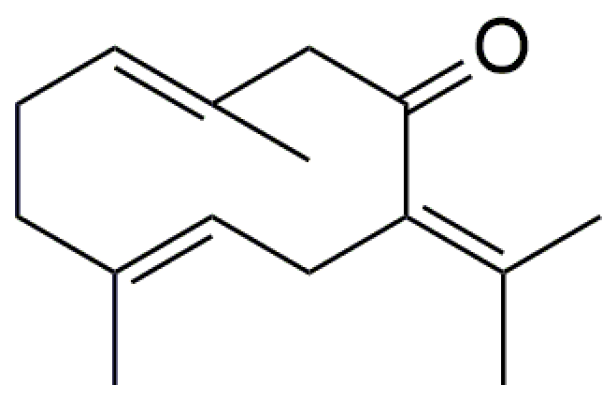

Figure 1: Structure of germacrone.

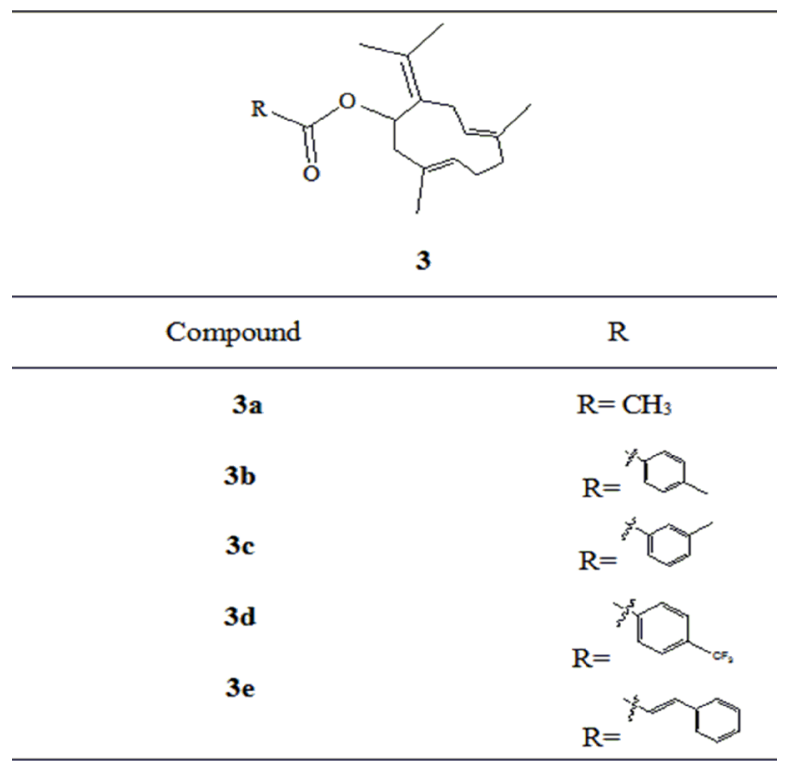

Figure 2: Germacrone derivatives. 
1H), 2.39 (t, J = 4.2 Hz, 1H), 2.37 (d, J = 1.8 Hz, 1H), 2.35 $(\mathrm{dd}, \mathrm{J}=3.1,1.6 \mathrm{~Hz}, 1 \mathrm{H}), 2.33(\mathrm{t}, \mathrm{J}=2.1 \mathrm{~Hz}, 1 \mathrm{H}), 2.31(\mathrm{~m}$, $1 \mathrm{H}), 2.10(\mathrm{~s}, 3 \mathrm{H}), 1.77(\mathrm{~s}, 6 \mathrm{H}), 1.58(\mathrm{~s}, 3 \mathrm{H}), 1.55(\mathrm{~s}, 3 \mathrm{H})$. ${ }^{13} \mathrm{C}$ NMR (100 MHz, (D) DMSO) $\delta 169.9$ (C-16), 138.3 (C-11), 137.2 (C-4), 131.7 (C-10), 129.4 (C-1), 129.2 (C-7), 120.1 (C-5), 73.7 (C-8), 39.2 (C-3), 38.6 (C-9), 28.8 (C-6), 25.6 (C-2), 21.4 (C-12, C-13), 20.9 (C-17), 18.8 (C-14), 16.3 (C-15). EI-MS: $263.20\left[\mathrm{M}+\mathrm{H}^{+}\right]$. Anal.Calcd for $\mathrm{C}_{16} \mathrm{H}_{24} \mathrm{O}_{2}$ (262.19): C, 77.82; H, 9.99; O, 12.20. Found: C, 77.80; H, 9.98; O, 12.22.

(3E,7E)-3,7-dimethyl-10-(propan-2-ylidene)

cyclodeca-3,7-dien-1-yl-4-methylbenzoate (3b) Yield: $62 \%,{ }^{1} \mathrm{H}$ NMR (400 MHz, $\mathrm{CDCl}_{3}$ ) $\delta 7.92$ (dd, J = 8.5, 1.7 $\mathrm{Hz}, 2 \mathrm{H}), 7.15$ (dd, J = 8.5, 1.7 Hz, 2H), 5.54 (dd, J = 5.6, $1.6 \mathrm{~Hz}, 1 \mathrm{H}), 5.32$ (dd, J = 11.1, 9.6 Hz, 1H), 5.17-5.09 $(\mathrm{m}, 1 \mathrm{H}), 2.55(\mathrm{~d}, \mathrm{~J}=10.0 \mathrm{~Hz}, 1 \mathrm{H}), 2.52(\mathrm{~d}, \mathrm{~J}=8.4 \mathrm{~Hz}$, $1 \mathrm{H}), 2.43$ (d, J = 1.9 Hz, 1H), 2.39 (s, 1H), 2.38 (s, 1H), $2.33(\mathrm{~s}, 1 \mathrm{H}), 2.32(\mathrm{~d}, \mathrm{~J}=1.6 \mathrm{~Hz}, 3 \mathrm{H}), 2.32-2.30(\mathrm{~m}, 2 \mathrm{H})$, $1.77(\mathrm{~s}, 6 \mathrm{H}), 1.58(\mathrm{~s}, 3 \mathrm{H}), 1.57(\mathrm{~s}, 3 \mathrm{H}) .{ }^{13} \mathrm{C}$ NMR $(100$ $\left.\mathrm{MHz},\left(\mathrm{D}_{6}\right) \mathrm{DMSO}\right) \delta 165.6$ (C-16), 139.7 (C-20), 138.2 (C-11), 137.1 (C-4), 133.8 (C-17), 131.6 (C-10), 129.4 (C-1), 129.2 (C-7), 129.1 (C-18, C-22), 129 (C-19, C-21), 120.1 (C-5), 73.7 (C-8), 39.2 (C-3), 38.6 (C-9), 28.8 (C-6), 25.6 (C-2), 21.4 (C-12, C-13), 21.2 (C-23), 18.8 (C-14), 16.3 (C-15). EI-MS: 339.23[M+H $\left.{ }^{+}\right]$. Anal.Calcd for $\mathrm{C}_{23} \mathrm{H}_{30} \mathrm{O}_{2}(338.22)$ : C, 81.61; H, 8.93; O, 9.45. Found: C, 81.61; H, 8.95; O, 9.43.

(3E,7E)-3,7-dimethyl-10-(propan-2-ylidene)

cyclodeca-3,7-dien-1-yl-3-methylbenzoate (3c) Yield: 47\%, ${ }^{1} \mathrm{H}$ NMR (400 MHz, $\mathrm{CDCl}_{3}$ ) $\delta$ 8.00-7.97 (m, 1H), $7.96(\mathrm{~s}, 1 \mathrm{H}), 7.50(\mathrm{t}, \mathrm{J}=8.0 \mathrm{~Hz}, 1 \mathrm{H}), 7.40-7.35(\mathrm{~m}, 1 \mathrm{H})$, $5.54(\mathrm{dd}, \mathrm{J}=5.6,1.6 \mathrm{~Hz}, 1 \mathrm{H}), 5.32(\mathrm{dd}, \mathrm{J}=11.3,10.0 \mathrm{~Hz}$, $1 \mathrm{H}), 5.16-5.09(\mathrm{~m}, 1 \mathrm{H}), 2.56(\mathrm{dd}, \mathrm{J}=12.3,10.5 \mathrm{~Hz}, 1 \mathrm{H})$, 2.53-2.50 (m, 1H), 2.48-2.46 (m, 1H), $2.43(\mathrm{~d}, \mathrm{~J}=1.7 \mathrm{~Hz}$, $3 \mathrm{H}), 2.39$ (s, 1H), $2.38(\mathrm{~d}, \mathrm{~J}=3.7 \mathrm{~Hz}, 1 \mathrm{H}), 2.32$ (d, J = $1.6 \mathrm{~Hz}, 1 \mathrm{H}), 2.32-2.25(\mathrm{~m}, 2 \mathrm{H}), 1.77(\mathrm{~s}, 6 \mathrm{H}), 1.58(\mathrm{~s}, 3 \mathrm{H})$, 1.57 (s, 3H). ${ }^{13} \mathrm{C}$ NMR (100 MHz, (D $)$ DMSO) $\delta 165.1$ (C-16), 138.2 (C-11), 138.2 (C-19), 137.1 (C-4), 132.6 (C-22), 131.7 (C-10), 130.6 (C-18), 130.5 (C-20), 129.4 (C-1), 129.2 (C-7), 128.4 (C-21), 126.8 (C-17), 120.1 (C-
5), 73.7 (C-8), 39.2 (C-3), 38.6 (C-9), 28.8 (C-6), 25.6 (C-2), 21.4 (C-12,C-13), 20.9 (C-23), 18.8 (C-14), 16.3 (C-15). EI-MS: $339.26\left[\mathrm{M}+\mathrm{H}^{+}\right]$. Anal.Calcd for $\mathrm{C}_{23} \mathrm{H}_{30} \mathrm{O}_{2}$ (338.22): C, 81.61; H, 8.93; O, 9.45.Found: C, 81.62; H, $8.92 ; \mathrm{O}, 9.45$.

(3E,7E)-3,7-dimethyl-10-(propan-2-ylidene) cyclodeca-3,7-dien-1-yl-4-(trifluoromethyl)benzoate (3d) Yield: 53\%, ${ }^{1} \mathrm{H}$ NMR (400 MHz, $\left.\mathrm{CDCl}_{3}\right) \delta 7.95$ (d, $\mathrm{J}=8.6 \mathrm{~Hz}, 2 \mathrm{H}), 7.86(\mathrm{~d}, \mathrm{~J}=8.6 \mathrm{~Hz}, 2 \mathrm{H}), 5.53(\mathrm{dd}, \mathrm{J}=$ $5.4,1.9 \mathrm{~Hz}, 1 \mathrm{H}), 5.32(\mathrm{dd}, \mathrm{J}=11.0,10.0 \mathrm{~Hz}, 1 \mathrm{H}), 5.16-$ $5.09(\mathrm{~m}, 1 \mathrm{H}), 2.57$ (dd, J = 10.4, 8.6 Hz, 1H), 2.52 (dd, $\mathrm{J}=10.3,7.4 \mathrm{~Hz}, 1 \mathrm{H}), 2.44-2.39(\mathrm{~m}, 1 \mathrm{H}), 2.39(\mathrm{~s}, 1 \mathrm{H})$, 2.38-2.34 (m, 2H), 2.32 (d, J = 1.6 Hz, 1H), 2.32-2.25 $(\mathrm{m}, 1 \mathrm{H}), 1.77(\mathrm{~s}, 6 \mathrm{H}), 1.58(\mathrm{~s}, 3 \mathrm{H}), 1.51(\mathrm{~s}, 3 \mathrm{H}) .{ }^{13} \mathrm{C}$ NMR (100 MHz, (D $)$ DMSO) $\delta 165.6$ (C-16), 138.3 (C-11), 137.2 (C-4), 133.8 (C-17), 132 (C-20), 131.6 (C-10), 129.4 (C-1), 129.2 (C-7), 129.1 (C-18, C-22), 125.1 (C-19, C-21), 124 (C-23), 120.1 (C-5), 73.7 (C-8), 39.2 (C-3), 38.6 (C-9), 28.8 (C-6), 25.6 (C-2), 21.4 (C-12, C-13), 18.8 (C-14), 16.3 (C-15). EI-MS: 393.20[M+H $\left.\mathrm{H}^{+}\right]$. Anal.Calcd for $\mathrm{C}_{23} \mathrm{H}_{27} \mathrm{~F}_{3} \mathrm{O}_{2}$ (392.20): $\mathrm{C}$, 70.39; H, 6.93; O, 8.15. Found: C, 70.39; H, 6.95; O, 8.15.

(Z)-(3E,7E)-3,7-dimethyl-10-(propan-2-ylidene)

cyclodeca-3,7-dien-1-yl-3-phenylacrylate (3e) Yield: 60\%, ${ }^{1} \mathrm{H}$ NMR (400 MHz, $\left.\mathrm{CDCl}_{3}\right) \delta 7.66(\mathrm{~d}, \mathrm{~J}=16.4 \mathrm{~Hz}, 1 \mathrm{H})$, 7.45 (dd, J = 6.5, 1.6 Hz, 1H), 7.44-7.40 (m, 2H), 7.40-7.35 $(\mathrm{m}, 2 \mathrm{H}), 6.69(\mathrm{~d}, \mathrm{~J}=16.1 \mathrm{~Hz}, 1 \mathrm{H}), 5.46(\mathrm{dd}, \mathrm{J}=5.6,1.6 \mathrm{~Hz}$, $1 \mathrm{H}), 5.32$ (dd, J = 11.1, 9.6 Hz, 1H), $5.16-5.09$ (m, 1H), $2.56(\mathrm{dd}, \mathrm{J}=13.1,11.3 \mathrm{~Hz}, 1 \mathrm{H}), 2.53-2.48(\mathrm{~m}, 1 \mathrm{H}), 2.43$ $(\mathrm{d}, \mathrm{J}=1.6 \mathrm{~Hz}, 1 \mathrm{H}), 2.40-2.38(\mathrm{~m}, 1 \mathrm{H}), 2.38-2.34$ (m, 2H), 2.33 (d, J = 1.7 Hz, 1H), 2.32-2.25 (m, 1H), 1.77 (s, 6H), $1.58(\mathrm{~s}, 3 \mathrm{H}), 1.53$ (s, 3H). ${ }^{13} \mathrm{C}$ NMR (100 MHz, (D) DMSO) $\delta 167$ (C-16), 144.4 (C-18), 138.3 (C-11), 137.2 (C-4), 134.4 (C-19), 131.6 (C-10), 129.4 (C-1), 129.2 (C-7), 128.9 (C-22), 128.7 (C-21, C-23), 127.3 (C-20, C-24), 120.1 (C-5), 115.9 (C-17), 73.7 (C-8), 39.2 (C-3), 38.6 (C-9), 28.8 (C-6), 25.6 (C-2), 21.4 (C-12,C-13), 18.8 (C-14), 16.3 (C-15). EI-MS: 351.23[M+H $\left.\mathrm{H}^{+}\right]$. Anal.Calcd for $\mathrm{C}_{24} \mathrm{H}_{30} \mathrm{O}_{2}$ (350.22): C, 82.24; H, 8.63; O, 9.13. Found: C, 82.22; H, $8.63 ; \mathrm{O}, 9.15$.

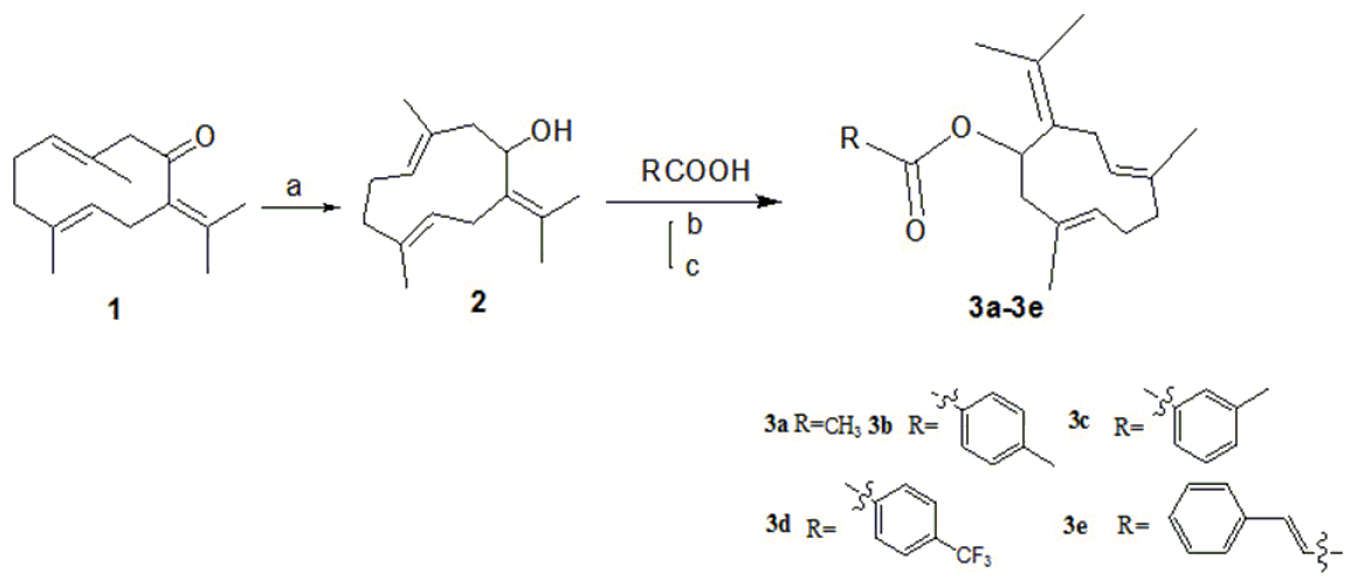

Scheme 1: Synthesis of 3a-3e. 


\section{Evaluation of biological activity}

Biological activities were evaluated by investigating the effect of germacrone and its derivatives on HepG2, A549, Bel-7402 and HeLa cells. Cells were treated with compounds at the concentrations of $12.5 \mu \mathrm{mol} / \mathrm{L}$, $25 \mu \mathrm{mol} / \mathrm{L}, \quad 50 \mu \mathrm{mol} / \mathrm{L}, 100 \mu \mathrm{mol} / \mathrm{L}, 200 \mu \mathrm{mol} / \mathrm{L}$, $400 \mu \mathrm{mol} / \mathrm{L}$ and $800 \mu \mathrm{mol} / \mathrm{L}$, respectively. MTT assay was then applied at $24 \mathrm{~h}, 48 \mathrm{~h}$. As shown in Table 1. The proliferations of HepG2, Bel7402, A549 and HeLa cells were inhibited in a dose-dependent manner, and cytolytic activity was markedly inhibited at the same time. The growth-inhibitory effect had no significant differences after incubation with germacrone and derivatives for $24 \mathrm{~h}$ and $48 \mathrm{~h}$ (Figure 3), so there was no great influence to the anti-proliferation effect of germacrone and derivatives on Bel-7402, HepG2, A549 and HeLa cells with the extended treatment time after $24 \mathrm{~h}$. However, all the compounds were active against Bel-7402, HepG2, A549 and HeLa cells to some extent. Inhibitions of germacrone derivatives (3a-3e) on these cells were stronger than germacrone and these results indicated that introduction of carboxylic esters could increase anticancer activity of germacrone, so we could elementary make sure that designed compounds should be well worth studying based on preliminary biological tests.
Compound $3 \mathrm{~b}$ was found to show highest activity against HepG2 cell line with an $\mathrm{IC}_{50}$ value of $68.23 \mu \mathrm{M}$. Since references reported that germacrone induced apoptosis by inhibiting Bcl-2 expression and inducing p 53 and Bax expression and induced cell cycle arrest and apoptosis through mitochondria-mediated caspase pathway, and induced apoptosis in human hepatoma HepG2 cells through inhibition of the JAK2/STAT3 signaling pathway [17-19]. Before we began to design these compounds, we carefully studied these references. Firstly, we hoped that designed compounds had stronger broad spectrum anti-tumor activities so we investigated their inhibitions on Bel-7402, HepG2, A549 and HeLa cells compared to germacrone. The results showed that these compounds, especially compound $3 \mathrm{~b}$ had better effect on HepG2 cell than other cells. Then we investigated mechanism according to above-mentioned documents, but the pre-experimental results showed no effect reported in these references. Hu C T, et al., Wang SY, et al. and Xie B, et al. reported that HepG2 was inhibited by inhibiting c-Met/HGF signaling pathway. Because c-Met kinase is expressed in a number of cancers and our research area is major in finding novel c-Met inhibitors so we investigated inhibition of germacrone derivatives on c-Met kinase [20-22]. The results of compounds on c-Met kinase showed that germacrone derivatives were active

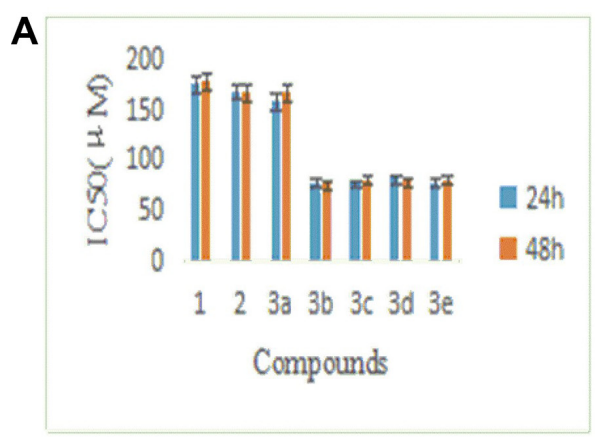

The effect of compounds on proliferation of Bel- 7402 cells

B

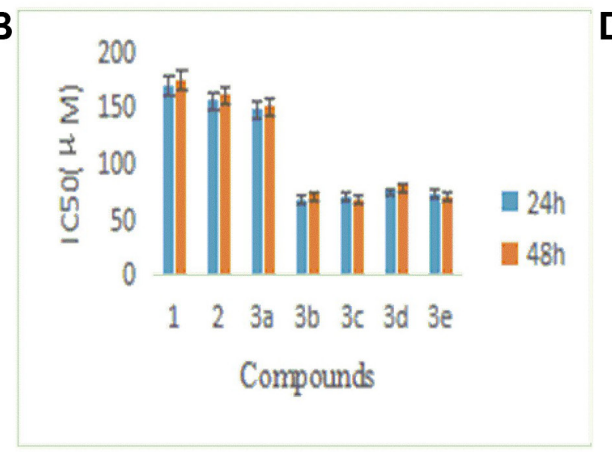

The effect of compounds on proliferation of HepG2 cells

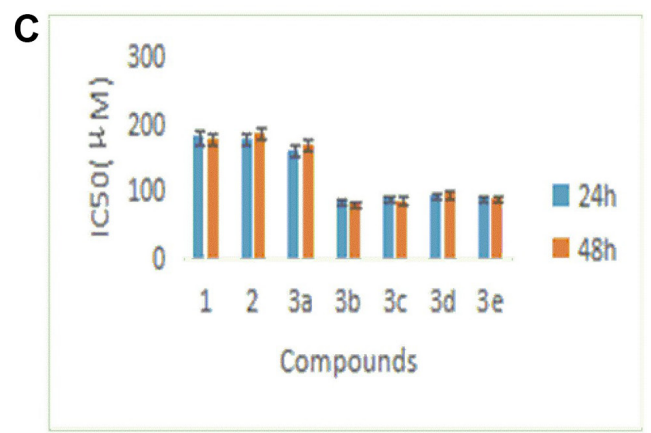

The effect of compounds on proliferation of A549 cells

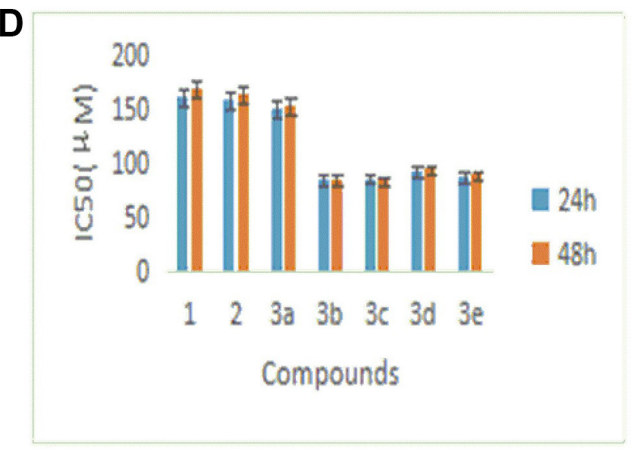

The effect of compounds on proliferation of Hela cells

Figure 3: Inhibition of germacrone derivatives on Bel-7402, HepG2, A549 and Hela cells. 
Table 1: $\mathrm{IC}_{50}$ values of compounds on Bel-7402, HepG2, A549 and Hela cells

\begin{tabular}{|c|c|c|c|c|c|c|c|c|}
\hline \multirow{2}{*}{ Compound } & \multicolumn{2}{|c|}{ Bel-7402 IC s0 $_{50}(\mu \mathrm{M})$} & \multicolumn{2}{|c|}{ HepG2 IC $_{50}(\mu \mathrm{M})$} & \multicolumn{2}{|c|}{ A549 IC ${ }_{50}(\mu M)$} & \multicolumn{2}{|c|}{ Hela $\mathrm{IC}_{50}(\mu \mathrm{M})$} \\
\hline & $24 \mathrm{~h}$ & $48 \mathrm{~h}$ & $24 \mathrm{~h}$ & $48 \mathrm{~h}$ & $24 \mathrm{~h}$ & $48 \mathrm{~h}$ & $24 \mathrm{~h}$ & $48 \mathrm{~h}$ \\
\hline 1 & $173.54 \pm 1.53$ & $177.21 \pm 1.97$ & $169.52 \pm 2.07$ & $174.56 \pm 1.88$ & $179.97 \pm 2.14$ & $177.21 \pm 1.87$ & $160.69 \pm 1.54$ & $167.78 \pm 1.81$ \\
\hline 2 & $167.08 \pm 1.91$ & $166.32 \pm 1.83$ & $155.2 \pm 1.75$ & $161.54 \pm 1.32$ & $177.21 \pm 1.80$ & $185.24 \pm 1.99$ & $157.31 \pm 1.47$ & $163.15 \pm 1.73$ \\
\hline $3 \mathbf{a}$ & $157.32 \pm 1.33$ & $166.25 \pm 1.51$ & $147.67 \pm 1.47$ & $151.59 \pm 1.71$ & $162.2 \pm 1.55$ & $168.87 \pm 1.74$ & $149.32 \pm 1.33$ & $152.95 \pm 1.65$ \\
\hline $3 b$ & $75.85 \pm 0.96$ & $74.16 \pm 0.83$ & $68.23 \pm 0.69$ & $71.47 \pm 0.82$ & $84.85 \pm 0.71$ & $81.87 \pm 0.88$ & $83.64 \pm 0.73$ & $83.78 \pm 0.76$ \\
\hline $3 c$ & $75.5 \pm 1.05$ & $78.55 \pm 0.51$ & $70.21 \pm 0.87$ & $67.84 \pm 0.48$ & $88.52 \pm 0.53$ & $87.21 \pm 0.94$ & $84.1 \pm 0.71$ & $82.54 \pm 0.64$ \\
\hline 3d & $80.14 \pm 1.19$ & $77.56 \pm 0.77$ & $74.66 \pm 0.99$ & $78.85 \pm 0.77$ & $93.48 \pm 0.79$ & $95.93 \pm 0.97$ & $91.25 \pm 0.87$ & $93.31 \pm 0.90$ \\
\hline $3 e$ & $75.87 \pm 0.81$ & $79.22 \pm 0.89$ & $72.48 \pm 0.64$ & $69.98 \pm 0.68$ & $90.11 \pm 0.75$ & $88.21 \pm 0.81$ & $86.55 \pm 0.80$ & $88.24 \pm 0.84$ \\
\hline
\end{tabular}

Table 2: $\mathrm{IC}_{50}$ values of compounds against c-Met kinase

\begin{tabular}{cccccccc}
\hline Compound & $\mathbf{1}$ & $\mathbf{2}$ & $\mathbf{3 a}$ & $\mathbf{3 b}$ & $\mathbf{3 c}$ & $\mathbf{3 d}$ & $\mathbf{3 e}$ \\
\hline $\mathrm{IC}_{50}(\mu \mathrm{M})$ & 1.15 & 1.77 & 1.06 & 0.56 & 0.83 & 0.92 & 0.87 \\
\hline
\end{tabular}

against c-Met kinase with $\mathrm{IC}_{50}$ values of $1.06 \mu \mathrm{M}, 0.56 \mu \mathrm{M}$, $0.83 \mu \mathrm{M}, 0.92 \mu \mathrm{M}, 0.87 \mu \mathrm{M}$, respectively (shown in Table 2). In accordance with the results of cells, the $\mathrm{IC}_{50}$ values of 3a-3e were lower than germacrone, in which $3 \mathrm{~b}$ had the best inhibitory effect with $\mathrm{IC}_{50}$ value of $0.56 \mu \mathrm{M}$ (Figure 4, Supplementary Table 1). The results suggested that derivatives had good activity so we could initially confirm that designed compounds might well repay investigation on the basis of preliminary activity tests. Further research works on activities are currently under investigation and will be reported in due course.

\section{Docking studies}

In pre-experiment, we carried out docking experiment by using several pdb proteins including 3DKF, 2WGJ, 2RFS and 3DKC. Only 3DKC interacted with germacrone and derivatives owing to sesquiterpene structures and 3DKC was used frequently in our experiment so we chose it to make docking experiment. The $3 \mathrm{DKC}$ is the crystal structure of c-Met kinase in complex with ATP and its information is seen from http://www.rcsb.org/pdb/explore/materialsAndMethods. do? structureId $=3 \mathrm{DKC}$.

Docking experiments indicated that there was a binding mode between our synthesized compounds and the active site of protein $3 \mathrm{dkc}$ (shown in Figure 5). The (E, E)-1, 5-cyclodecadiene system interacted with the protein crystal $3 \mathrm{dkc}$ strongly by hydrophobic force and $\pi-\pi$ stacking interaction of the benzene ring group. Compound $3 \mathrm{~b}$ showed highest activity owing to hydrophobic interaction of methyl as shown in Figure 6. The binding energies were shown in Table 3 . The compound $3 \mathrm{~b}$ also had stronger binding energies and inhibition, in which $\mathrm{R}$ was methyl substituted benzene.

\section{MD simulations and $\Delta \mathrm{Gpred}$ calculation}

Molecular docking experiments gave a probably momentary binding mode that could be unreasonable and unstable. Molecular dynamics simulations were applied to perform further study of binding stabilities between compound (1-3e) and 3DKC. The crystal structures of 3DKC complex with $1-3$ e were used to evaluate the reliability of MD simulations. The RMSD curve and the surface area curve of the $1 \mathrm{~ns}$ indicated that $3 \mathrm{~b}$ was relatively stable and the trajectories were well smoothly and other compounds were unstable with uneven trajectories (shown in Figure 7 and Supplementary Figure 1 to Supplementary Figure 7 ). The MD parameters were appropriate for the MD simulations.

The 2 3DKC-ligand complexes were performed by $8 \mathrm{~ns}$ MD simulations under identical MD conditions and all compounds gave stable RMSD curves during their MD simulations. $\Delta$ Gpred were selected and ordered or $3 \mathrm{DKC}$ inhibitory activity assessment which values more negative than $-25 \mathrm{kcal} / \mathrm{mol}$. The predicted $\Delta$ Gpred value of the $3 \mathrm{~b}$ 
Table 3: Binding energies of complexes between compounds and 3DKC

\begin{tabular}{cccc}
\hline Compounds & $\mathbf{R}$ & $\mathbf{c - M e t}$ Inhibition rate (\%) & -CDOCKER energy (Kcal/mol) \\
\hline $\mathbf{1}$ & - & $27 \%$ & 29.9587 \\
$\mathbf{2}$ & $-\mathrm{OH}$ & $23 \%$ & 22.5548 \\
$\mathbf{3 a}$ & $\mathrm{Me}$ & $31 \%$ & 22.8715 \\
$\mathbf{3 b}$ & $56 \%$ & 65.2361 \\
$\mathbf{3 c}$ & $47 \%$ & 51.0112 \\
$\mathbf{3 d}$ & $38 \%$ & 40.1487 \\
$\mathbf{3 e}$ & $41 \%$ & 45.2356 \\
\hline
\end{tabular}

compound was $-28.36 \mathrm{kcal} / \mathrm{mol}$ while predicted $\Delta$ Gpred value of other compounds were more than $-25 \mathrm{kcal} / \mathrm{mol}$ (shown in Table 4).

\section{MATERIALS AND METHODS}

\section{Chemicals and reagents}

All chemicals were obtained from Aladdin or J\&K. Solvents were purified and dried by standard procedures, and stored over $3-\AA$ molecular sieves. Reactions were followed by TLC using SILG/UV 254 silica-gel plates. Flash chromatography (FC): silica gel ( $\mathrm{SiO} 2 ; 40 \mu \mathrm{m}$, 230-400 mesh). ${ }^{1} \mathrm{H}$ NMR and ${ }^{13} \mathrm{C}$ NMR Spectra: Bruker Digital NMR Spectrometer, rep. $\delta$ in ppm, J in Hz. EI-MS: Waters ZQ4000. Cells were obtained from China Center for Type Culture Collection of Wuhan University; c-Met kinase were purchased from Millipore (Billerica, MA); RPMI-1640culture medium and new-born calf serum from Gibco (GrandIsland,NY); Methyl thiazolyl tetrazolium (MTT)was purchased from Amresco (Solon, OH).

\section{Synthesis of compounds}

\section{Synthesis of 2}

The suspension of $\mathrm{LiAlH}_{4}(3.8 \mathrm{mg}, 0.1 \mathrm{mmol})$ was added to a cold $\left(-10^{\circ} \mathrm{C}\right)$ solution of $1(21.8 \mathrm{mg}, 0.1 \mathrm{mmol})$ in THF $(15 \mathrm{ml})$ under argon and vigorous stirring. After $1 \mathrm{~h}$ (TLC control) the reaction was stopped by successive addition of water (2 drops), $6 \mathrm{~N} \mathrm{NaOH}$ solution (2 drops) and water (4 drops). The mixture was extracted with DCM $(3 \times 20 \mathrm{ml})$ to give a crude product which was purified by silica gel column chromatography (hexane : t-butyl methyl ether, 70:30) to obtain 2 (18.3 $\mathrm{mg}, 84 \%)$.

\section{Synthesis of 3a}

A mixture of acetic acid ( $9 \mathrm{mg}, 0.15 \mathrm{mmol}), \mathrm{SOCl}_{2}$ (21.4 mg, $0.18 \mathrm{mmol})$, DMF 2 drops and DCM $(5 \mathrm{ml})$ was refluxed for $4 \mathrm{~h}$ to obtain acetyl chloride. Acetyl chloride $(11.8 \mathrm{mg}, 0.15 \mathrm{mmol})$ was added portion wise to a solution of $2(21.9 \mathrm{mg}, 0.1 \mathrm{mmol})$, Py $(15.8 \mathrm{mg}$, $0.2 \mathrm{mmol})$ in THF $(15 \mathrm{ml})$ under nitrogen at $0^{\circ} \mathrm{C}$. Then,

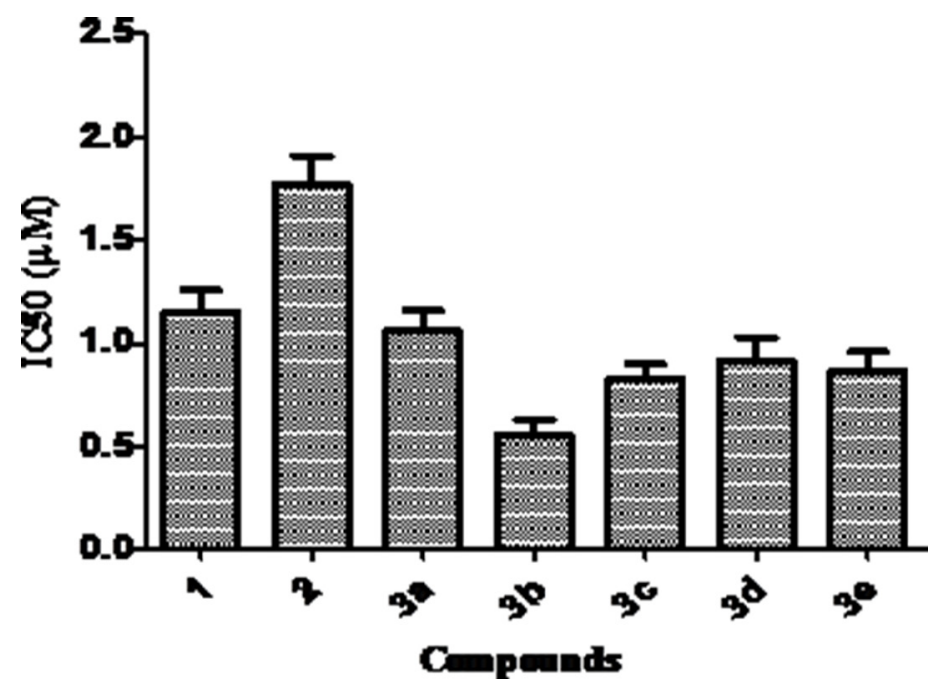

Figure 4: Inhibition of germacrone derivatives on c-Met kinase 
Table 4: The value of -CDOCKER energy

\begin{tabular}{cccc}
\hline Compounds & $\mathbf{R}$ & c-Met Inhibition rate (\%) & -DeltaGpred Energy (kcal/mol) \\
\hline $\mathbf{1}$ & $-\mathrm{OH}$ & $27 \%$ & 16.35 \\
$\mathbf{2}$ & $23 \%$ & 12.31 \\
$\mathbf{3 a}$ & $\mathrm{Me}$ & $31 \%$ & 19.69 \\
$\mathbf{3 b}$ & $56 \%$ & 28.07 \\
$\mathbf{3 c}$ & $47 \%$ & 27.14 \\
$\mathbf{3 d}$ & $38 \%$ & 20.88 \\
$\mathbf{3 e}$ & $41 \%$ & 21.28 \\
\hline
\end{tabular}

the mixture was stirred for $4 \mathrm{~h}$ at r.t. (TLC control), the solution was filtered. The solvent was removed under reduced pressure, and the crude product was purified by column chromatography (ethyl/acetat, 80/20) to obtain the target product $3 \mathrm{a}(17.4 \mathrm{mg}, 67 \%)$.

\section{Synthesis of $\mathbf{3 b}$}

A mixture of $2(21.9 \mathrm{mg}, 0.1 \mathrm{mmol})$, DMAP (6.1 mg, $0.05 \mathrm{mmol})$, para-toluic acid (13.6 mg, $0.1 \mathrm{mmol}$ ) and DCM $(10 \mathrm{ml})$ was stirred for $30 \mathrm{~min}$ under nitrogen at $-10^{\circ} \mathrm{C}$, then, a solution of DCC $(41.2 \mathrm{mg}, 0.2 \mathrm{mmol})$ in DCM $(5 \mathrm{ml})$ was added slowly and the mixture was stirred vigorously for $24 \mathrm{~h}$ at r.t. and filtered. The solvent was removed under reduced pressure to give a crude product which was purified by column chromatography to obtain the product $3 \mathrm{~b}(20.8 \mathrm{mg}, 62 \%)$.

\section{Synthesis of 3c, 3d and 3e} to $3 b$.

Compounds $3 \mathrm{c}, 3 \mathrm{~d}$ and $3 \mathrm{e}$ were prepared in analogy

\section{Cell culture}

Bel-7402 cells, HepG2 cells (Human hepatoma cell line), A-549 and HeLa cells were investigated according to related reference [23] and the cells were cultured in RPMI 1640 and DMEM media supplemented with 10\% FBS and
$1 \% \mathrm{P} / \mathrm{S}$ (100 units/ml peni cillin and $100 \mathrm{mg} / \mathrm{ml}$ streptomycin), respectively, at $37^{\circ} \mathrm{C}$ in a $5 \% \mathrm{CO}_{2}$ atmosphere.

\section{Cell assay}

Proliferation of cells was evaluated by MTT assay [10]. Cells were inoculated at $1.0 \times 10^{4}$ cells $/ \mathrm{mL}$ with $200 \mu \mathrm{L}$ in each well of 96-well plate and allowed to adhere to the plates overnight. Then the cells were treated with a range of concentrations $(0-800 \mu \mathrm{mol} / \mathrm{L})$ of target products or $0.1 \%$ DMSO for 24,48 h. $20 \mu \mathrm{L}$ of MTT was added to each well and incubated at $37^{\circ} \mathrm{C}$ in dark for $4 \mathrm{~h}$. After removal of the medium, cells were treated with $150 \mu \mathrm{L}$ of DMSO and shaken for 15 min to completely dissolve the formazan crystals. The absorbances at $590 \mathrm{~nm}$ of the dissolved solutions were detected using a SpectraMAX190 microplate reader (Molecular Devices, USA).

\section{Inhibition of c-Met kinase}

The inhibitions of c-Met kinase were investigated referred to a published literature [24]. The $\mathrm{IC}_{50}$ values were detected using TR-FRET. $50 \mathrm{nM} 6$ His-tagged recombinant human c-Met residues 974-end (Millipore) was cultured in medium containing $2.5 \mathrm{~m} \mathrm{~mol} / \mathrm{L} \mathrm{MnCl}_{2}$, $10 \mathrm{~m} \mathrm{~mol} / \mathrm{L} \mathrm{MgCl}_{2}, 20 \mathrm{~m} \mathrm{~mol} / \mathrm{L}$ Tris, $2 \mathrm{~m} \mathrm{~mol} / \mathrm{L}$ DTT and

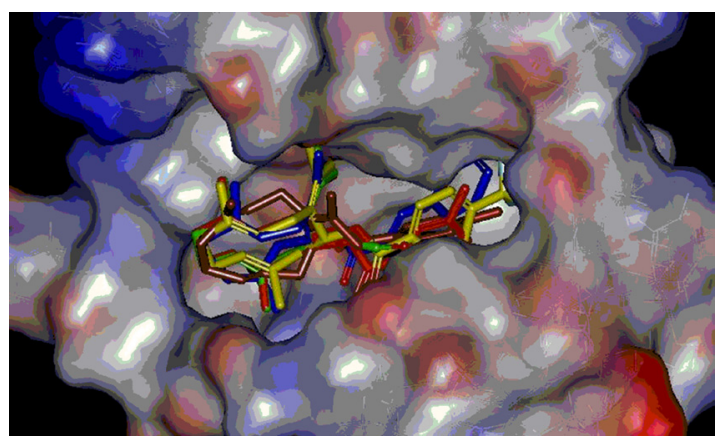

Figure 5: Compact binding modes of all compounds (PDB code: $3 \mathrm{dkc}$ ). 
$0.01 \%$ Tween 20 with $5 \mathrm{~m} \mathrm{~mol} / \mathrm{L}$ ATP and $200 \mathrm{n} \mathrm{mol} / \mathrm{L}$ 5FAM-KKK -SPGEYVNIGFG-NH ${ }_{2}$ with $25 \mu \mathrm{L}$ at room temperature for $60 \mathrm{~min}$. Compounds were made up to $100 \mu \mathrm{M}$ solutions and were tested with 10 concentration gradients by two times dilutions. Each group was tested for three times Reactions were termined by IMAP stop solution. Plates were incubated for an overnight and analyzed by using AiphaQuest.

\section{Molecular docking}

Molecular docking was performed according to related reference [25].The docking experiment was carried out with CDocker program which was connected with Accelrys Discovery Studio 2.5.5. The programs adapted an empirical scoring function and a patented searching engine [26-27]. Briefly, ligands were docked into the corresponding protein's binding site complied with protocol, which was generated by ligand from the crystal structure of 3DKC with random hydrogen atoms and GasteigereHückel charges but not water and ligands other parameters were default values except that the threshold was 1 . The structure of receptor was minimized to 10,000 cycles using Powell method in DS 2.5.5. The geometries of all compounds were optimized by conjugate gradient method of TRIPOS. The convergence criterion was identified as $0.001 \mathrm{kcal} / \mathrm{mol}$.

\section{MD simulations}

The MD simulations were performed on the basis of molecular docking by using AMBER 10.0 for ligands and AMBER ff03 for protein, and using Gaussian 03 program to calculate partial atomic charges at a neutral $\mathrm{pH}$, with histidines 164 and 200 protonated at $\delta$ position,

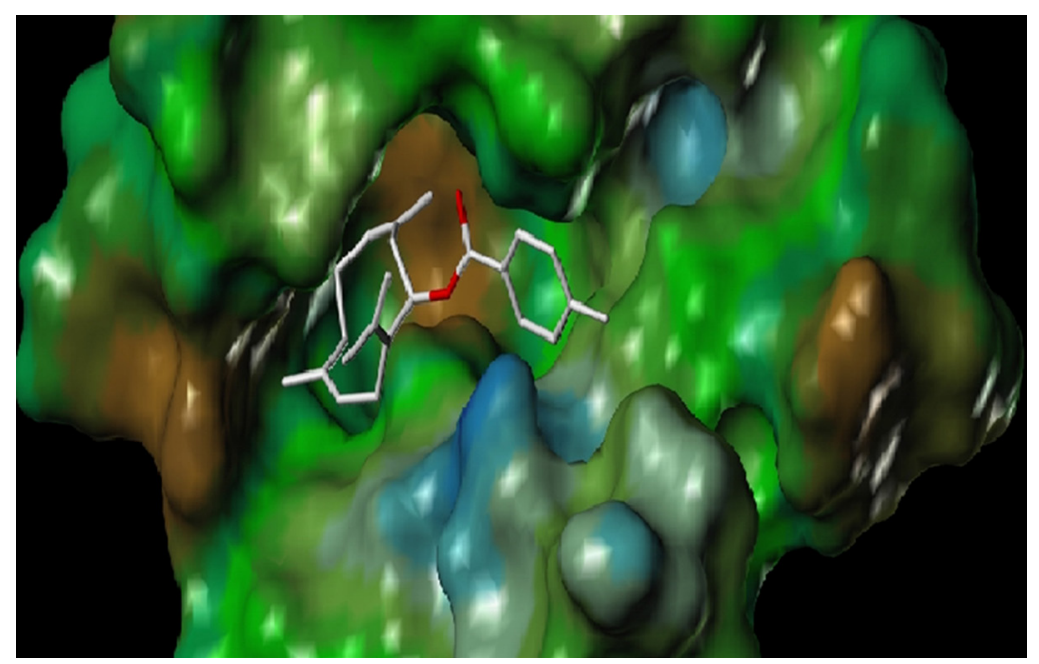

Figure 6: Conformation of $\mathbf{3 b .}$

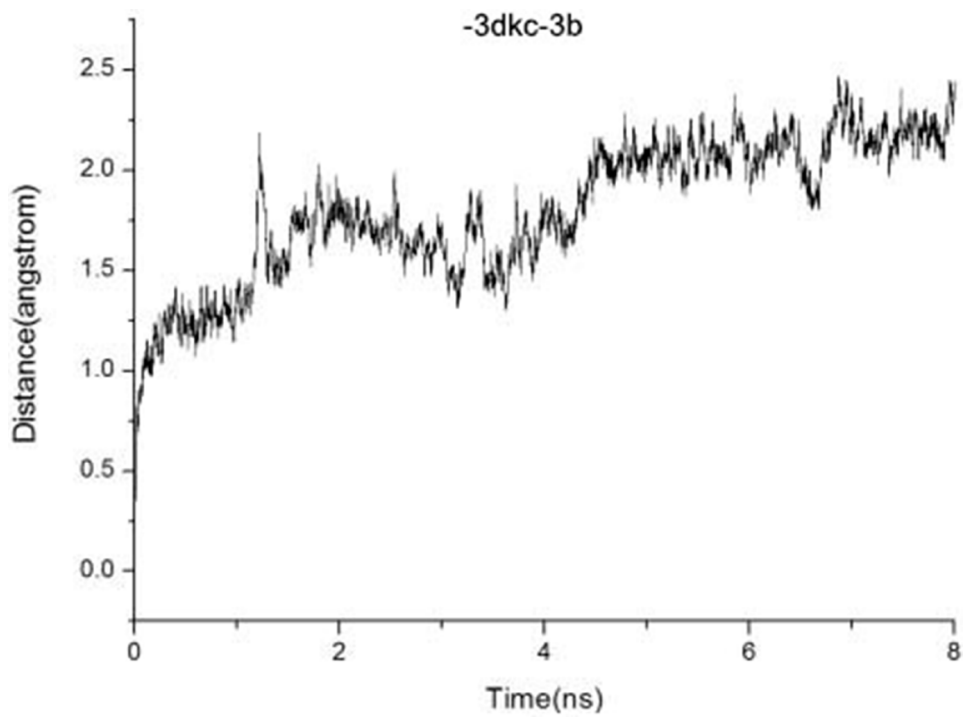

Figure 7: Plots of RMSD for all of the backbone atoms ( $\AA$ ) vs simulation time (ns) for $3 D K C$ in complex with $3 b$. 
and using SHAKE algorithm to restrict all the bonds given the time step of 2 fs and cutoff distance of $8 \AA$ with long-range electrostatic interactions treated with the particle mesh Ewald (PME) method [28-30]. The heating operation was carried out from 0 to $300 \mathrm{~K}$ in 50 ps using Langevin dynamics at a constant volume and equilibrated for $100 \mathrm{ps}$ at a constant pressure of 1 atm after four steps of minimizations, which included 2500 cycles of steepest descent minimization, followed by 2500 cycles of conjugated gradient minimization. Heavy atoms of receptor-ligand complex were restrained to $0,10,100$, and $500 \mathrm{kcal} /$ (mol $\AA 2$ ) and were $10 \mathrm{kcal} /$ (mol A2) during the heating and equilibration steps while solvent molecules were not restricted. Finally, periodic boundary conditions of 8 ns were performed for the whole system with normal pressure of $1 \mathrm{~atm}$ and normal temperature of $300 \mathrm{~K}$ in the production step.

\section{MM-PBSA estimation of binding free energy $\Delta$ Gpred}

For each system, $\Delta$ Gpred values were calculated using 100 snapshots recorded from the last with $1 \mathrm{~ns}$ trajectory an interval of 10 ps by Molecular Mechanics Poisson-Boltzmann Surface Area method [31-34].

\section{CONCLUSIONS}

The present study designed and synthesized novel compounds using germacrone as leading compound based on the combination principles. The results indicated that the major of compounds had moderate inhibition on cancer cells and c-Met kinase and introduction of carboxylic esters could increase anticancer activity of germacrone. These compounds can be further researched as antitumor leading structure and supply reference for developing anticancer with clinical value. The results of molecular docking and MD simulations were very important to explain molecular mechanism of eminent activities to c-Met kinase and binding stabilities between compounds and their receptors and these results can provide theoretical basis for further research c-Met inhibitors.

\section{Abbreviations}

DMSO, dimethyl sulfoxide; THF, tetrahydrofuran; DCC, dicyclohexylcarbodiimide; DMF, N, N-dimethyl formamide; DMAP, 4-dimethylaminopyridine; NMR, Nuclear Magnetic Resonance; TCL, thinlayer chromato -graphy; DCM, dichloromethane; EI-MS, electron impact spectrometry; MTT, 3-(4, 5-dimethylthiazol-2-yl)-2,5 -diphenyltetrazolium bromide.

\section{CONFLICTS OF INTEREST}

The authors declare no competing financial interest.

\section{FUNDING}

This study was supported by The Guangdong Strategic Emerging Project of Guangdong Provincial Department of Science and Technology (No. 2012A080800012), Special Fund of Applied Research and Development of Guangdong Provincial Department of Science and Technology (2015B020234009), Special Fund for TCM supported by State Administration of Traditional Chinese Medicine of China (201507004), The Joint Natural Sciences Fund of The Department of Science and Technology and The First Affiliated Hospital of Guangdong Pharmaceutical University (No.GYFYLH201317), Guangdong Natural Science Foundation (2015A030313586), and Science and Technology Planning Project of Guangdong Province (Guangdong Branch Regulations [2015]110). The authors are grateful to Mr Tan and Sun Yet-Sen University for molecular docking experiment.

\section{REFERENCES}

1. Chen W, Lu Y, Gao M, Wu J, Wang A, Shi R. Antiangiogenesis effect of essential oil from Curcuma zedoaria in vitro and in vivo. J Ethnopharmacol. 2011; 133:220-26.

2. Matsuda H, Tewtrakul S, Morikawa T, Nakamura A, Yoshikawa M. Anti-allergic principles from Thai zedoary: structural requirements of curcuminoids for inhibition of degranulation and effect on the release of TNF- $\alpha$ and IL-4 in RBL-2H3 cells. Bioorg Med Chem. 2004; 12:5891-98.

3. Seo WG, Hwang JC, Kang SK, Jin UH, Suh SJ, Moon SK, Kim CH. Suppressive effect of Zedoariae rhizoma on pulmonary metastasis of B16 melanoma cells. J Ethnopharmacol. 2005; 101:249-57.

4. Chen CC, Chen Y, Hsi YT, Chang CS, Huang LF, Ho CT, Way TD, Kao JY. Chemical constituents and anticancer activity of Curcuma zedoaria roscoe essential oil against non-small cell lung carcinoma cells in vitro and in vivo. J Agric Food Chem. 2013; 61:11418-27.

5. Navarro DF, de Souza MM, Neto RA, Golin V, Niero R, Yunes RA, Delle Monache F, Cechinel Filho V. Phytochemical analysis and analgesic properties of Curcuma zedoaria grown in Brazil. Phytomedicine. 2002; 9:427-32.

6. Wilson B, Abraham G, Manju VS, Mathew M, Vimala B, Sundaresan S, Nambisan B. Antimicrobial activity of Curcuma zedoaria and Curcuma malabarica tubers. J Ethnopharmacol. 2005; 99:147-51.

7. Dang YY, Li XC, Zhang QW, Li SP, Wang YT. Preparative isolation and purification of six volatile compounds from essential oil of Curcuma wenyujin using high-performance centrifugal partition chromatography. J Sep Sci. 2010; 33:1658-64.

8. Cho W, Nam JW, Kang HJ, Windono T, Seo EK, Lee KT. Zedoarondiol isolated from the rhizoma of Curcuma heyneana is involved in the inhibition of iNOS, COX-2 and pro-inflammatory cytokines via the downregulation of NFkappaB pathway in LPS-stimulated murine macrophages. Int Immunopharmacol. 2009; 9:1049-57. 
9. Xiao X, Zhao Y, Yuan H, Xia W, Zhao J, Wang X. [Study on the effect of Rhizoma Curcuma Longa on gastrin receptor]. [Article in Chinese]. Zhong Yao Cai. 2002; 25:184-85.

10. Liu Y, Wang W, Fang B, Ma F, Zheng Q, Deng P, Zhao S, Chen M, Yang G, He G. Anti-tumor effect of germacrone on human hepatoma cell lines through inducing G2/M cell cycle arrest and promoting apoptosis. Eur J Pharmacol. 2013; 698:95-102.

11. Schmidt L, Duh FM, Chen F, Kishida T, Glenn G, Choyke P, Scherer SW, Zhuang Z, Lubensky I, Dean M, Allikmets R, Chidambaram A, Bergerheim UR, et al. Germline and somatic mutations in the tyrosine kinase domain of the MET proto-oncogene in papillary renal carcinomas. Nat Genet. 1997; 16:68-73.

12. Ma PC, Kijima T, Maulik G, Fox EA, Sattler M, Griffin JD, Johnson BE, Salgia R. c-MET mutational analysis in small cell lung cancer: novel juxtamembrane domain mutations regulating cytoskeletal functions. Cancer Res. 2003; 63:6272-81.

13. Ma PC, Jagadeesh $\mathrm{S}$, Jagadeeswaran $\mathrm{R}$, Fox EA, Christensen J, Maulik G, Naoki K, Schaefer E, Lader A, Richards W, Sugarbaker D, Meyerson M, Salgia R. c-MET expression/activation, functions, and mutations in non-small cell lung cancer. Cancer Res. 2004; 64:430-431.

14. Di Renzo MF, Olivero M, Martone T, Maffe A, Maggiora P, Stefani AD, Valente G, Giordano S, Cortesina G, Comoglio PM. Somatic mutations of the MET oncogene are selected during metastatic spread of human HNSC carcinomas. Oncogene. 2000; 19:1547-55.

15. Lee JH, Han SU, Cho H, Jennings B, Gerrard B, Dean M, Schmidt L, Zbar B, Vande Woude GF. A novel germ line juxtamembrane Met mutation in human gastric cancer. Oncogene. 2000; 19:4947-53.

16. Feng Y, Thiagarajan PS, Ma PC. MET signaling: novel targeted inhibition and its clinical development in lung cancer. J Thorac Oncol. 2012; 7:459-67.

17. Xie XH, Zhao H, Hu YY, Gu XD. Germacrone reverses Adriamycin resistance through cell apoptosis in multidrugresistant breast cancer cells. Exp Ther Med. 2014; 8:1611-15.

18. Zhong Z, Chen X, Tan W, Xu Z, Zhou K, Wu T, Cui L, Wang Y. Germacrone inhibits the proliferation of breast cancer cell lines by inducing cell cycle arrest and promoting apoptosis. Eur J Pharmacol. 2011; 667:50-55.

19. Liu YY, Zheng Q, Fang B, Wang W, Ma FY, Roshan S, Banafa A, Chen MJ, Chang JL, Deng XM, Li KX, Yang GX, He GY. Germacrone induces apoptosis in human hepatoma HepG2 cells through inhibition of the JAK2/ STAT3 signalling pathway. J Huazhong Univ Sci Technolog Med Sci. 2013; 33:339-45.

20. Hu CT, Cheng CC, Pan SM, Wu JR, Wu WS. PKC mediates fluctuant ERK-paxillin signaling for hepatocyte growth factor-induced migration of hepatoma cell HepG2. Cell Signal. 2013; 25:1457-67.

21. Wang SY, Chen B, Zhan YQ, Xu WX, Li CY, Yang RF, Zheng H, Yue PB, Larsen SH, Sun HB, Yang X. SU5416 is a potent inhibitor of hepatocyte growth factor receptor (c-Met) and blocks HGF-induced invasiveness of human HepG2 hepatoma cells. J Hepatol. 2004; 41:267-73.

22. Xie B, Tang C, Chen P, Gou YB, Xiao J, Du H. [The effect of hepatitis $\mathrm{B}$ virus $\mathrm{X}$ protein on the c-met promoter activity in HepG2 cells]. [Article in Chinese]. Zhonghua Gan Zang Bing Za Zhi. 2009; 17:292-96.

23. Chen W, Liu Y, Li M, Mao J, Zhang L, Huang R, Jin X, Ye L. Anti-tumor effect of $\alpha$-pinene on human hepatoma cell lines through inducing $\mathrm{G} 2 / \mathrm{M}$ cell cycle arrest. J Pharmacol Sci. 2015; 127:332-38.

24. Buchanan SG, Hendle J, Lee PS, Smith CR, Bounaud PY, Jessen KA, Tang CM, Huser NH, Felce JD, Froning KJ, Peterman MC, Aubol BE, Gessert SF, et al. SGX523 is an exquisitely selective, ATP-competitive inhibitor of the MET receptor tyrosine kinase with antitumor activity in vivo. Mol Cancer Ther. 2009; 8:3181-90.

25. Ye L, Tian Y, Li Z, Jin H, Zhu Z, Wan S, Zhang J, Yu P, Zhang J, Wu S. Design, synthesis and molecular docking studies of some novel spiro[indoline-3, 4'-piperidine]-2ones as potential c-Met inhibitors. Eur J Med Chem. 2012; 50:370-75.

26. Jain AN. Surflex: fully automatic flexible molecular docking using a molecular similarity-based search engine. J Med Chem. 2003; 46:499-511.

27. Jain AN. Surflex-Dock 2.1: robust performance from ligand energetic modeling, ring flexibility, and knowledge-based search. J Comput Aided Mol Des. 2007; 21:281-306.

28. Vay JL, Fawley W. AMBER User's Manual. Interim Report. 2008; 3:22-5.

29. Frisch MJ, Trucks GW, Schlegel HB, et al. Gaussian 03, Revision E.01; Gaussian, Inc.: Pittsburgh PA. 2004.

30. Miyamoto S, Kollman PA. Settle: an analytical version of the SHAKE and RATTLE algorithm for rigid water models. J Comput Chem. 1992; 13:952-62.

31. Massova I, Kollman PA. Combined molecular mechanical and continuum solvent approach (MM-PBSA/GBSA) to predict ligand binding. Perspect Drug Discov Des. 2000; 18:113-15.

32. Hou T, Wang J, Li Y, Wang W. Assessing the performance of the MM/PBSA and MM/GBSA methods. 1. The accuracy of binding free energy calculations based on molecular dynamics simulations. J Chem Inf Model. 2011; 51:69-82.

33. Liu M, Yuan M, Luo M, Bu X, Luo HB, Hu X. Binding of curcumin with glyoxalase I: molecular docking, molecular dynamics simulations, and kinetics analysis. Biophys Chem. 2010; 147:28-34.

34. He L, He F, Bi H, Li J, Zeng S, Luo HB, Huang M. Isoformselective inhibition of chrysin towards human cytochrome P450 1A2. Kinetics analysis, molecular docking, and molecular dynamics simulations. Bioorg Med Chem Lett. 2010; 20:6008-12. 